\title{
Studies of the Mechanism of Contralateral Polyuria
}

\section{after Renal Artery Stenosis}

\author{
Oscar G. Galvez, Bertram W. Roberts, Michael H. Mishkind, William H. Bay, \\ and THOMAS F. Ferris \\ From the Department of Medicine, Ohio State University College of Medicine, Columbus, Ohio 43210
}

\begin{abstract}
A B S T RACT Acute renal artery stenosis in hydropenic dogs caused a contralateral increase in urine volume and free water clearance without change in glomerular filtration, renal blood flow, or osmolar clearance. The increase in urine volume was not dependent on the development of hypertension since it occurred in animals pretreated with trimethaphan but was dependent upon angiotensin since it was prevented with angiotensin blockade with Saralasin. The effect was not caused by angiotensin inhibiting antidiuretic hormone release since the polyuria occurred in hypophysectomized animals receiving a constant infusion of $10 \mu \mathrm{U} / \mathrm{kg}$ per min of aqueous Pitressin. Since the rise in urine volume was associated with an increase in renal vein prostaglandin $E$ concentration and was prevented by pretreatment with indomethacin $(5 \mathrm{mg} / \mathrm{kg})$ the results suggest that the rise in plasma angiotensin after renal artery stenosis causes an increase in contralateral prostaglandin $\mathrm{E}$ synthesis with resultant antagonism to antidiuretic hormone at the collecting tubule.
\end{abstract}

\section{INTRODUCTION}

Although fine control of antidiuretic hormone (ADH) ${ }^{1}$ release depends on change in plasma osmolality, nonosmotic factors are known to affect ADH secretion (1). Baroreceptors in the carotid sinus (2) and left atrium (3) alter ADH secretion through activation of the autonomic nervous system. Thus, acute elevation of blood pressure with either norepinephrine (4) (5) or angiotensin (6) increases free water clearance by suppressing ADH secretion but whether a change in the sensitivity of the collecting tubule to ADH occurs with hypertension is not clear. Fisher has demonstrated in subjects undergoing a water

\footnotetext{
${ }^{1}$ Abbreviations used in this paper: ADH, antidiuretic hormone; GFR, glomerular filtration rate; MAP, mean arterial pressure; PGE, prostaglandin E; Uosm, urine osmolality.

Received for publication 31 August 1976 and in revised form 22 November 1976.
}

diuresis that norepinephrine, in doses not changing glomerular filtration, reversed the effect of a vasopressin infusion (7). One potential mechanism for such a change in tubular sensitivity to $\mathrm{ADH}$ would be an alteration in medullary prostaglandin $E$ synthesis. Grantham and Orloff demonstrated in the isolated collecting tubule that prostaglandin $E_{1}$ in contact with the serosal side of the tubule antagonized the effect of vasopressin on water permeability (8). Since the renal medullary interstitial cells and collecting duct contain a high concentration of prostaglandin synthetase (9) (10), local synthesis of prostaglandin E (PGE) might affect collecting tubule ADH sensitivity. Angiotensin, norepinephrine, and renal nerve stimulation (11) are known to increase renal vein PGE concentration so it is possible that the water diuresis which occurs with these agents or maneuvers depends on both change in ADH secretion and in tubular sensitivity to ADH.

To investigate collecting tubule sensitivity to ADH during hypertension the effect of acute renal artery stenosis on contralateral renal function was studied in anesthetized hydropenic dogs. The results indicate that a contralateral polyuria develops after renal artery stenosis which is independent of ADH secretion and is caused by antagonism to the effect of ADH on the collecting tubule possibly induced by increased renal PGE synthesis.

\section{METHODS}

Mongrel dogs weighing from 15 to $25 \mathrm{~kg}$ that had been deprived of food and water for $18 \mathrm{~h}$ were studied. The animals were anesthetized with pentobarbital (30-35 $\mathrm{mg} / \mathrm{kg}$ ) and given additional doses as needed during the experiment. An endotracheal tube was inserted and the dogs ventilated with a Harvard respirator. (Harvard Apparatus Co., Inc., Millis, Mass.) Polyethylene catheters were placed in both ureters through a suprapubic incision. A GoodaleLubin catheter was placed via one femoral artery into the left ventricle for injection of radioactive microspheres labeled with either $\mathrm{Sr}^{85}, \mathrm{Ce}^{141}$, or $\mathrm{Cr}^{51}$ (3M Co., St. Paul, Minn.) and another catheter was inserted into the other femoral artery for pressure monitoring and blood sampling. 
TABLE I

Contralateral Renal Function

\begin{tabular}{|c|c|c|c|c|c|c|c|c|c|c|c|c|}
\hline \multirow[b]{3}{*}{ Period } & \multicolumn{3}{|c|}{ MAP } & \multicolumn{3}{|c|}{ GFR } & \multicolumn{3}{|c|}{ RBF } & \multicolumn{3}{|c|}{ UV } \\
\hline & \multicolumn{3}{|c|}{$m m H_{g}$} & \multicolumn{3}{|c|}{$m l / m i n$} & \multicolumn{3}{|c|}{$\mathrm{ml} / \mathrm{min}$} & \multicolumn{3}{|c|}{$\mathrm{ml} / \mathrm{min}$} \\
\hline & I & II & III & I & HI & III & I & II & III & I & II & III \\
\hline $\begin{array}{l}\text { Group I ( } \\
\text { Mean } \\
\pm \text { SEM }\end{array}$ & $\begin{array}{r}=6) \\
121 \\
\pm 3\end{array}$ & $\begin{array}{c}142 \\
\pm 3 \\
<0.001\end{array}$ & & $\begin{array}{r}24.9 \\
\pm 1.7\end{array}$ & $\begin{array}{c}22.3 \\
\pm 1.9 \\
\text { NS }\end{array}$ & & $\begin{array}{r}219 \\
\pm 24\end{array}$ & $\begin{array}{l}206 \\
\pm 22 \\
\text { NS }\end{array}$ & & $\begin{array}{r}0.52 \\
\pm 0.10\end{array}$ & $\begin{array}{r}1.20 \\
\pm 0.20 \\
<0.001\end{array}$ & \\
\hline $\begin{array}{l}\text { Group II } \\
\text { Mean } \\
\pm \text { SEM } \\
P\end{array}$ & $\begin{array}{c}n=6 \\
113 \\
\pm 3\end{array}$ & $\begin{array}{c}109 \\
\pm 3 \\
\text { NS }\end{array}$ & & $\begin{array}{r}26.3 \\
\pm 2.0\end{array}$ & $\begin{array}{l}27 \\
\pm 2.5 \\
\text { NS }\end{array}$ & & $\begin{array}{r}152 \\
\pm 12\end{array}$ & $\begin{array}{l}143 \\
\pm 14 \\
\text { NS }\end{array}$ & & $\begin{array}{r}0.50 \\
\pm 0.10\end{array}$ & $\begin{array}{r}0.92 \\
\pm 0.10 \\
<0.005\end{array}$ & \\
\hline $\begin{array}{l}\text { Group III } \\
\text { Mean } \\
\pm \text { SEM } \\
P\end{array}$ & $\begin{array}{r}(n= \\
130 \\
\pm 4\end{array}$ & $\begin{array}{c}155 \\
\pm 4 \\
<0.001\end{array}$ & $\begin{array}{c}128 \\
\pm 4 \\
<0.001\end{array}$ & $\begin{array}{l}28 \\
\pm 2.0\end{array}$ & $\begin{array}{l}27 \\
\pm 2.0 \\
\text { NS }\end{array}$ & $\begin{array}{l}28 \\
\pm 1 \\
\text { NS }\end{array}$ & $\begin{array}{r}109 \\
\pm 14\end{array}$ & $\begin{array}{l}106 \\
\pm 20 \\
\text { NS }\end{array}$ & $\begin{array}{l}117 \\
\pm 12 \\
\text { NS }\end{array}$ & $\begin{array}{r}0.58 \\
\pm 0.15\end{array}$ & $\begin{array}{r}1.22 \\
\pm 0.40 \\
<0.05\end{array}$ & $\begin{array}{r}0.63 \\
\pm 0.15 \\
<0.05\end{array}$ \\
\hline $\begin{array}{l}\text { Group IV } \\
\text { Mean } \\
\pm \text { SEM }\end{array}$ & $\begin{array}{c}n=6 \\
114 \\
\pm 6\end{array}$ & $\begin{array}{c}146 \\
\pm 4 \\
<0.001\end{array}$ & $\begin{array}{r}151 \\
\pm 4 \\
\text { NS }\end{array}$ & $\begin{array}{l}22 \\
\pm 1.2\end{array}$ & $\begin{array}{l}21 \\
\pm 1.2 \\
N S\end{array}$ & $\begin{array}{l}21 \\
\pm 1.4 \\
\text { NS }\end{array}$ & $\begin{array}{r}112 \\
\pm 10\end{array}$ & $\begin{array}{l}108 \\
\pm 11 \\
\text { NS }\end{array}$ & $\begin{array}{l}120 \\
\pm 10 \\
\text { NS }\end{array}$ & $\begin{array}{r}0.48 \\
\pm 0.10\end{array}$ & $\begin{array}{r}0.76 \\
\pm 0.15 \\
<0.01\end{array}$ & $\begin{aligned} & 0.55 \\
\pm & 0.1 \\
< & 0.005\end{aligned}$ \\
\hline $\begin{array}{l}\text { Group V } \\
\text { Mean } \\
\pm \text { SEM } \\
P\end{array}$ & $\begin{array}{c}=5 \\
121 \\
\pm 3\end{array}$ & $\begin{array}{c}154 \\
\pm 5 \\
<0.001\end{array}$ & & $\begin{array}{l}26 \\
\pm 1.6\end{array}$ & $\begin{array}{l}24 \\
\pm 1.0 \\
\text { NS }\end{array}$ & & $\begin{array}{r}116 \\
\pm 12\end{array}$ & $\begin{array}{c}150 \\
\pm 28 \\
\text { NS }\end{array}$ & & $\begin{array}{r}0.20 \\
\pm 0.20\end{array}$ & $\begin{array}{c}0.35 \\
\pm 0.05 \\
\text { NS }\end{array}$ & \\
\hline
\end{tabular}

Abbreviations: $\mathrm{C}_{\mathrm{H}_{0}}$, free water clearance; Cosm, osmolar clearance; PRA, plasma renin activity

The right renal vein was cannulated via the femoral vein and peripheral venous lines were established for infusion of pharmacological agents. The left renal artery was carefully dissected to its origin for placement of a variably constricting snare. Iothalamate ${ }^{125}$ (Golfil, Abbott Laboratories, North Chicago, Ill.) in saline was infused at $1 \mathrm{ml} / \mathrm{min}$ for measurement of glomerular filtration rate (GFR). Total renal blood flow and fractional cortical blood flow were determined by the radioactive microsphere method previously described (12) (13). Arterial blood pressure was monitored by a Statham strain gauge (Statham Instruments, Inc., Oxnard, Calif.) connected to a Hewlett-Packard polygraph. (Hewlett-Packard Co., Palo Alto, Calif.) The mean of three 10-min urine collections were obtained for all clearance data.

Plasma renin was measured by the method of Haber et al., after incubation for $3 \mathrm{~h}$ at $\mathrm{pH} 5.5$ (14). Plasma PGE was determined by immunoassay with a method previously described (15). Osmolar and free water clearance were cal-

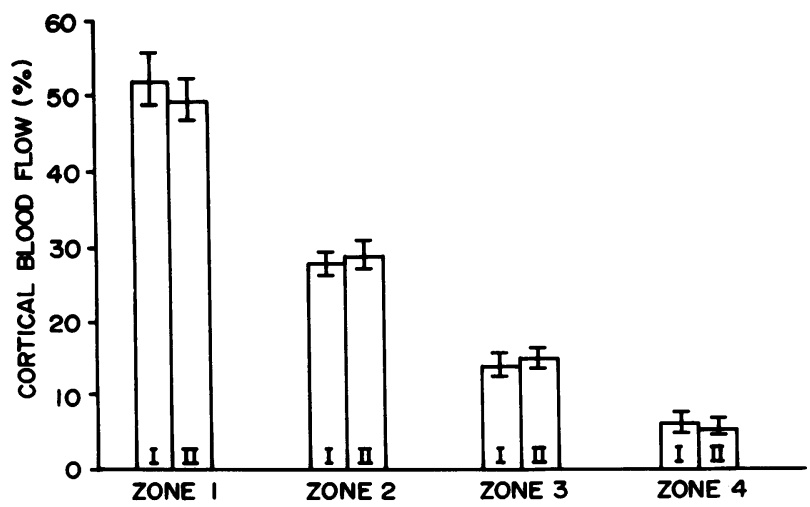

FIGURE 1 Renal cortical blood flow distribution in the contralateral kidney before (Period I) and after (Period II) renal artery stenosis. Zones are numbered 1-4 from outer to inner cortex. culated in the usual manner. Data is reported as mean Istandard error and the Wilcoxon rank test was used for statistical analysis of the paired results. Five groups of experiments were conducted.

Group I-contralateral renal function during acute renal artery stenosis. Mean arterial pressure (MAP) was recorded continuously and collections for urine volume, GFR, urine sodium excretion, and osmolality were obtained before (Period I) and $1 \mathrm{~h}$ after constriction of the left renal artery (Period II). At the completion of the experiment the contralateral kidney was removed for determination of fractional cortical and total renal blood flow.

Group II-Arfonad infusion. This protocol was similar to Group I except that during stenosis of the left renal artery an infusion of trimethaphan (Arfonad) in isotonic saline maintained MAP at control values. The infusion was continued for $1 \mathrm{~h}$ and repeat determinations of contralateral renal function obtained (Period II).

Group III-angiotensin blockade. Three experimental periods were obtained: control (Period I); $1 \mathrm{~h}$ after renal artery stenosis (Period II); and $1 \mathrm{~h}$ after an infusion of Saralasin (1 sarcosine, 8 alanine, angiotensin II) (Eaton Laboratories, Norwich, N. Y.) $20 \mu \mathrm{g} / \mathrm{kg}$ per min (Period III).

Group IV-hypophysectomized dogs. Total hypophysectomy and cauterization of the supraoptic nuclei was performed by a modified Cushing transtemporal approach. The animals received dexamethasone, $1 \mathrm{mg}$ i.v., immediately after surgery and urine volume was replaced with normal saline. After evidence of diabetes insipidus appeared (urine osmolality $<150 \mathrm{mosM} / \mathrm{kg}$ per $\mathrm{H}_{2} \mathrm{O}$ and urine volume $>4-5$ cubic centimeters $/ \mathrm{min}$ ) a $10 \mu \mathrm{U} / \mathrm{kg}$ per $\mathrm{min}$ infusion of aqueous vasopressin (Parke, Davis \& Co., Detroit, Mich.) was begun. The urine volume and osmolality were stabilized in the same range as nonhypophysectomized animals and control collections were obtained (Period I). The left renal artery was then constricted and determinations repeated $1 \mathrm{~h}$ later (Period II). The dose of Pitressin was increased to $80 \mu \mathrm{U} / \mathrm{kg}$ per min for $1 \mathrm{~h}$ and repeat studies obtained (Period III).

Group V-prostaglandin inhibition. The animals 


\begin{tabular}{|c|c|c|c|c|c|c|c|c|c|c|c|c|c|c|}
\hline \multicolumn{3}{|c|}{$\mathrm{U}_{\mathrm{Na}} \mathrm{V}$} & \multicolumn{3}{|c|}{ Cosm } & \multicolumn{3}{|c|}{ Uosm } & \multicolumn{3}{|c|}{$\mathrm{C}_{\mathrm{H}_{2} \mathrm{O}}$} & \multicolumn{3}{|c|}{ PRA } \\
\hline \multicolumn{3}{|c|}{ req/min } & \multicolumn{3}{|c|}{$\mathrm{ml} / \mathrm{min}$} & \multicolumn{3}{|c|}{$\mathrm{mosm} / \mathrm{kg} / \mathrm{H}_{2} \mathrm{O}$} & \multicolumn{3}{|c|}{$\mathrm{ml} / \mathrm{min}$} & \multicolumn{3}{|c|}{$n g / m l / h$} \\
\hline I & II & III & I & II & III & I & II & III & I & II & III & I & II & III \\
\hline $\begin{array}{r}95 \\
\pm 16\end{array}$ & $\begin{array}{r}116 \\
\pm 17 \\
<0.01\end{array}$ & & $\begin{array}{l}1.46 \\
\pm 0.20\end{array}$ & $\begin{array}{c}1.39 \\
\pm 0.20 \\
\text { NS }\end{array}$ & & $\begin{array}{r}897 \\
\pm 74\end{array}$ & $\begin{array}{c}368 \\
\pm 22 \\
<0.001\end{array}$ & & $\begin{array}{l}-0.94 \\
\pm 0.1\end{array}$ & $\begin{array}{l}-0.19 \\
\pm 0.1 \\
<0.001\end{array}$ & & $\begin{array}{r}4.5 \\
\pm 1.0\end{array}$ & $\begin{array}{r}21.5 \\
\pm 33.0 \\
<0.001\end{array}$ & \\
\hline $\begin{array}{l}93 \\
\pm 2\end{array}$ & $\begin{array}{l}104 \\
\pm 12 \\
\text { NS }\end{array}$ & & $\begin{array}{r}1.36 \\
\pm 0.10\end{array}$ & $\begin{array}{c}1.28 \\
\pm 0.20 \\
\text { NS }\end{array}$ & & $\begin{aligned} & 835 \\
\pm & 65\end{aligned}$ & $\begin{array}{c}425 \\
\pm 21 \\
<0.005\end{array}$ & & $\begin{array}{l}-0.85 \\
\pm 0.3\end{array}$ & $\begin{array}{l}-0.36 \\
\pm 0.1 \\
<0.01\end{array}$ & & $\begin{array}{r}6.4 \\
\pm 1.7\end{array}$ & $\begin{array}{c}30.5 \\
\pm 9.4 \\
<0.001\end{array}$ & \\
\hline \multirow[t]{2}{*}{$\begin{array}{r}89 \\
\pm 20\end{array}$} & $\begin{array}{c}112 \\
\pm 25 \\
<0.025\end{array}$ & $\begin{array}{c}102 \\
\pm 24 \\
\text { NS }\end{array}$ & $\begin{array}{r}1.17 \\
\pm 0.23\end{array}$ & $\begin{array}{c}1.25 \\
\pm 0.24 \\
\mathrm{NS}\end{array}$ & $\begin{array}{c}1.32 \\
\pm 0.25 \\
\text { NS }\end{array}$ & $\begin{array}{r}691 \\
\pm 100\end{array}$ & $\begin{array}{c}361 \\
\pm 40 \\
<0.005\end{array}$ & $\begin{array}{r}673 \\
\pm 106 \\
<0.01\end{array}$ & $\begin{array}{l}-0.59 \\
\pm 0.12\end{array}$ & $\begin{array}{r}0.01 \\
\pm 0.15 \\
<0.02\end{array}$ & $\begin{array}{r}-0.65 \\
\pm 0.2 \\
<0.02\end{array}$ & $\begin{array}{r}5.6 \\
\pm 1.2\end{array}$ & $\begin{aligned} & 14.7 \\
+ & 2.5 \\
< & 0.001\end{aligned}$ & $\begin{array}{r}26.3 \\
\pm 5.4 \\
<0.01\end{array}$ \\
\hline & $\begin{array}{l}100 \\
\pm 14 \\
\text { NS }\end{array}$ & $\begin{array}{r}99 \\
\pm 27 \\
\text { NS }\end{array}$ & $\begin{array}{r}1.00 \\
\pm 0.12\end{array}$ & $\begin{array}{c}1.10 \\
\pm 0.15 \\
\text { NS }\end{array}$ & $\begin{array}{c}1.10 \\
\pm 0.20 \\
\text { NS }\end{array}$ & $\begin{array}{r}722 \\
\pm 46\end{array}$ & $\begin{array}{c}480 \\
\pm 28 \\
<0.005\end{array}$ & $\begin{aligned} & 673 \\
\pm & 68 \\
< & 0.01\end{aligned}$ & $\begin{array}{l}-0.55 \\
\pm 0.05\end{array}$ & $\begin{array}{c}-0.32 \\
\pm 0.04 \\
<0.005\end{array}$ & $\begin{array}{r}-0.52 \\
\pm 0.1 \\
<0.01\end{array}$ & $\begin{array}{r}4.4 \\
\pm 1.1\end{array}$ & $\begin{array}{c}12.7 \\
\pm 2.5 \\
<0.001\end{array}$ & $\begin{array}{l}12.7 \\
\pm 2.5 \\
\text { NS }\end{array}$ \\
\hline $\begin{array}{l}15 \\
\pm 3\end{array}$ & $\begin{array}{c}38 \\
\pm 4 \\
<0.02\end{array}$ & & $\begin{array}{r}0.58 \\
\pm 0.03\end{array}$ & $\begin{array}{c}0.96 \\
\pm 0.21 \\
\text { NS }\end{array}$ & & $\begin{array}{r}945 \\
\pm 60\end{array}$ & $\begin{array}{l}809 \\
\pm 72 \\
\text { NS }\end{array}$ & & $\begin{array}{l}-0.39 \\
\pm 0.03\end{array}$ & $\begin{array}{c}-0.6 \\
\pm 0.16 \\
\text { NS }\end{array}$ & & $\begin{array}{r}4.0 \\
\pm 1.4\end{array}$ & $\begin{array}{c}16.3 \\
\pm 6.9 \\
<0.01\end{array}$ & \\
\hline
\end{tabular}

RBF, renal blood flow; $U V$, urine volume, $\mathrm{U}_{\mathrm{Na}} \mathrm{V}$, urine sodium excretion.

were given indomethacin, $5 \mathrm{mg} / \mathrm{kg}$ i.v., $1 \mathrm{~h}$ before the control period (Period I). $1 \mathrm{~h}$ after renal artery stenosis repeat studies were performed (Period II).

\section{RESULTS}

The results of all experiments are given in Table $\mathrm{I}$.

Group I. $1 \mathrm{~h}$ after constriction of the left renal artery MAP had risen from $121 \pm 3$ to $142 \pm 3 \mathrm{mmHg}$ $(P<0.001)$ with significant increase in contralateral urine volume from $0.52 \pm 0.1$ to $1.2 \pm 0.2 \mathrm{ml} / \mathrm{min}(P$ $<0.001)$. Urine osmolality decreased from $897 \pm 74$ to $368 \pm 22 \mathrm{mosM} / \mathrm{kg}$ per $\mathrm{H}_{2} \mathrm{O}(P<0.001)$, as free water clearance increased from $-0.94 \pm 0.1$ to -0.19 $\pm 0.1 \mathrm{ml} / \mathrm{min}(P<0.001)$. There was an increase in urinary sodium from $95 \pm 16$ to $116 \pm 17 \mu \mathrm{eq} / \mathrm{min}$ $(P<0.01)$ but no rise in osmolar clearance, $1.46 \pm 0.2$ before and $1.39 \pm 0.2 \mathrm{ml} / \mathrm{min}$ after renal artery stenosis. There was no change in renal blood flow; however, a small, but insignificant, decrease in glomerular filtration from $24.9 \pm 1.7$ to $22.3 \pm 1.9 \mathrm{ml} / \mathrm{min}$ occurred after induction of renal hypertension. The fall in GFR accounted for the unchanged osmolar clearance in spite of the significant natriuresis. Plasma renin activity increased in peripheral blood from $4.4 \pm 1.0$ to 21.5 $\pm 3.3 \mathrm{ng} / \mathrm{ml}$ per h $(P<0.001)$. Fractional cortical blood was unchanged in the contralateral kidney in Period I and II (Fig. 1).

Group II. In animals receiving intravenous Arfonad there was no change in mean arterial blood pressure, $113 \pm 3$ before and $109 \pm 3 \mathrm{mmHg}$ after renal artery stenosis. However, plasma renin increased from $6.4 \pm 1.7$ to $30.5 \pm 9.4 \mathrm{ng} / \mathrm{ml}$ per $\mathrm{h}(P<0.005)$. The increase in urine volume was associated with a fall in urine osmolality from $835 \pm 65$ to $425 \pm 21$ mos $\mathrm{M} / \mathrm{kg}$ per $\mathrm{H}_{2} \mathrm{O} \quad(P<0.005)$, rise in $\mathrm{C}_{\mathrm{H}_{2} \mathrm{O}}$ from $-0.85 \pm 0.30$ to $-0.36 \pm 0.10 \mathrm{ml} / \mathrm{min}(P<0.01)$, with no change in either osmolar clearance or urinary sodium. There was no change in contralateral renal blood flow or GFR during renal artery stenosis with Arfonad.

Group III. MAP increased from $130 \pm 4$ to $155 \pm 4$ $\mathrm{mmHg}(P<0.01)$ with induction of renal artery stenosis (Period II) and fell significantly to $128 \pm 4$ $(P<0.001)$ with Saralasin (Period III) (Fig. 2). Urine volume increased from $0.58 \pm 0.15$ to $1.22 \pm 0.40 \mathrm{ml} / \mathrm{min}$ $(P<0.05)$ in Period II and decreased to values not different from control, $0.63 \pm 0.15 \mathrm{ml} / \mathrm{min}$, with Saralasin. Urine osmolality (Uosm) which had de-
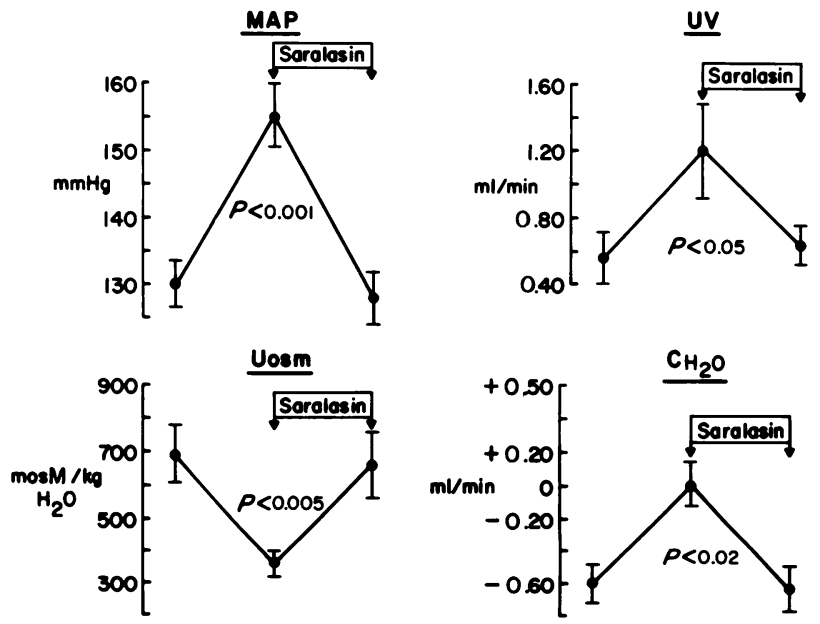

FIGURE 2 Renal artery stenosis with Saralasin. The effect of Saralasin in blocking the rise in MAP, contralateral urine volume (UV), Uosm, and free water clearance $\left(\mathrm{C}_{\mathrm{H}_{2} \mathrm{O}}\right)$ after renal artery stenosis. 

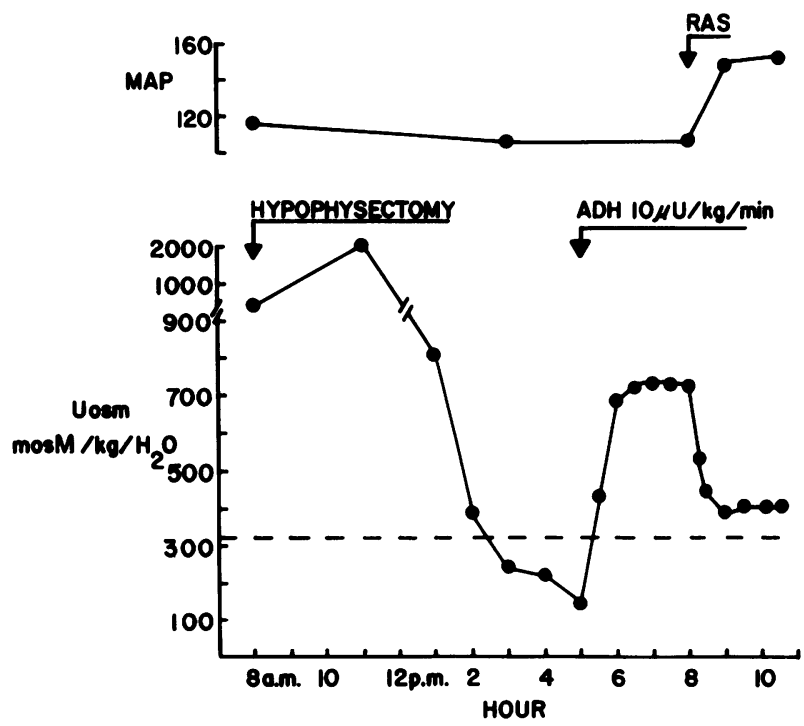

FIGURE 3 Renal artery stenosis with hypophysectomy and ADH. A typical experiment in Group IV. After hypophysectomy Uosm fell from 2,000 to $150 \mathrm{mosM} / \mathrm{kg}$ per $\mathrm{H}_{2} \mathrm{O}$. Renal artery stenosis (RAS) caused MAP to rise from 115 to $145 \mathrm{mmHg}$ and Uosm fell to $325 \mathrm{mosM} / \mathrm{kg}$ per $\mathrm{H}_{2} \mathrm{O}$ in spite of continuous Pitressin administration.

creased from $691 \pm 100$ to $361 \pm 40 \operatorname{mosM} / \mathrm{kg}$ per $\mathrm{H}_{2} \mathrm{O}$ $(P<0.005)$ after renal artery stenosis rose to $673 \pm 106$ $(P<0.01)$ with Saralasin as $\mathrm{C}_{\mathrm{H}_{2} O}$, which had risen from $-0.59 \pm 0.12(P<0.02)$ in Period I to $0.01 \pm 0.15$ in Period II $(P<0.02)$ fell to $-0.65 \pm 0.12 \mathrm{ml} / \mathrm{min}$ $(P<0.02)$ in Period III. There was no significant difference between $\mathrm{C}_{\mathrm{H}_{2} \mathrm{O}}$ in Period I or III. Urinary sodium excretion increased during renal artery stenosis from $89 \pm 20$ to $112 \pm 25 \mu \mathrm{eq} / \mathrm{min}(P<0.025)$ with no change during Saralasin. Plasma renin activity rose from $5.6 \pm 1.2$ to $14.7 \pm 2.5 \mathrm{ng} / \mathrm{ml}$ per $\mathrm{h}(P<0.001)$ after renal artery stenosis and increased further during Saralasin to $26.3 \pm 5.4(P<0.01)$. There was no change in GFR, renal blood flow, or osmolar clearance during the three periods.

Group IV. A typical Group IV experiment is demonstrated in Fig. 3. In this experiment after hypophysectomy Uosm fell over a period of 5-6 h to below $150 \mathrm{mosM} / \mathrm{kg}$ per $\mathrm{H}_{2} \mathrm{O}$ and urine volume increased to $4.5 \mathrm{ml} / \mathrm{min}$. $10 \mu \mathrm{U} / \mathrm{kg}$ per $\mathrm{min}$ of vasopressin caused Uosm to rise to 700 mos $M$ and urinary volume to decrease. After stenosis of the renal artery MAP rose from 120 to $158 \mathrm{mmHg}$ and Uosm fell from 700 to $320 \mathrm{mosM} / \mathrm{kg}$ per $\mathrm{H}_{2} \mathrm{O}$ during the continuous infusion of Pitressin. In six similar experiments renal artery stenosis caused a rise in arterial pressure from $114 \pm 6$ to $146 \pm 4 \mathrm{mmHg}(P<0.001)$ with a fall in Uosm from $722 \pm 46$ to $480 \pm 28 \mathrm{mosM} / \mathrm{kg}$ per $\mathrm{H}_{2} \mathrm{O}(P<0.005)$ and increase in urine volume from $0.48 \pm 0.10$ to $0.76 \pm 0.15 \mathrm{ml} / \mathrm{min}(P<0.01)$. Free water clearance increased from $-0.55 \pm 0.05$ to
$-0.32 \pm 0.04 \mathrm{ml} / \mathrm{min}(P<0.005)$ without change in osmolar clearance, urinary sodium, GFR, or renal blood flow. When vasopressin was increased to 80 $\mu \mathrm{U} / \mathrm{kg}$ per min in Period III, Uosm increased from $480 \pm 28$ to $673 \pm 68 \mathrm{mosM} / \mathrm{kg}$ per $\mathrm{H}_{2} \mathrm{O}(P<0.01)$ as urine volume decreased from $0.76 \pm 0.15$ to $0.55 \pm 0.10 \mathrm{ml} / \mathrm{min}$ $(P<0.005)$ and $\mathrm{C}_{\mathrm{H}_{2} \mathrm{O}}$ decreased from $-0.32 \pm 0.04$ to $-0.52 \pm 0.10 \mathrm{ml} / \mathrm{min}(P<0.001)$. The antagonism to $\mathrm{ADH}$ was thus demonstrated with $10 \mu \mathrm{U} / \mathrm{kg}$ per min vasopressin but not with $80 \mu \mathrm{U} / \mathrm{kg}$ per min.

Group $V$. These animals were given indomethacin, $5 \mathrm{mg} / \mathrm{kg}$ i.v., $1 \mathrm{~h}$ before the control period. Renal artery stenosis caused a rise in blood pressure from $121 \pm 3$ to $154 \pm 5 \mathrm{mmHg}(P<0.001)$ without significant change in urinary volume, $0.20 \pm 0.20$ vs. $0.35 \pm 0.05 \mathrm{ml} / \mathrm{min}$, or Uosm, $945 \pm 60$ vs. $809 \pm 72$ mosM/kg per $\mathrm{H}_{2} \mathrm{O}$. There was a significant increase in urinary sodium from $15 \pm 3$ to $38 \pm 4 \mu \mathrm{eq} / \mathrm{min}$ ( $P$ $<0.02$ ) with no change in GFR or renal blood flow.

In eight dogs not treated with indomethacin, contralateral renal vein PGE concentration was determined before and $1 \mathrm{~h}$ after renal artery constriction. Control PGE was $0.7 \pm 0.1$ which rose to 3.1 $\pm 1.1 \mathrm{ng} / \mathrm{ml}(P<0.01)$ after renal artery stenosis. In the animals treated with Indocin, renal vein PGE was $1.28 \pm 0.34 \mathrm{ng} / \mathrm{ml}$ in the contralateral kidney

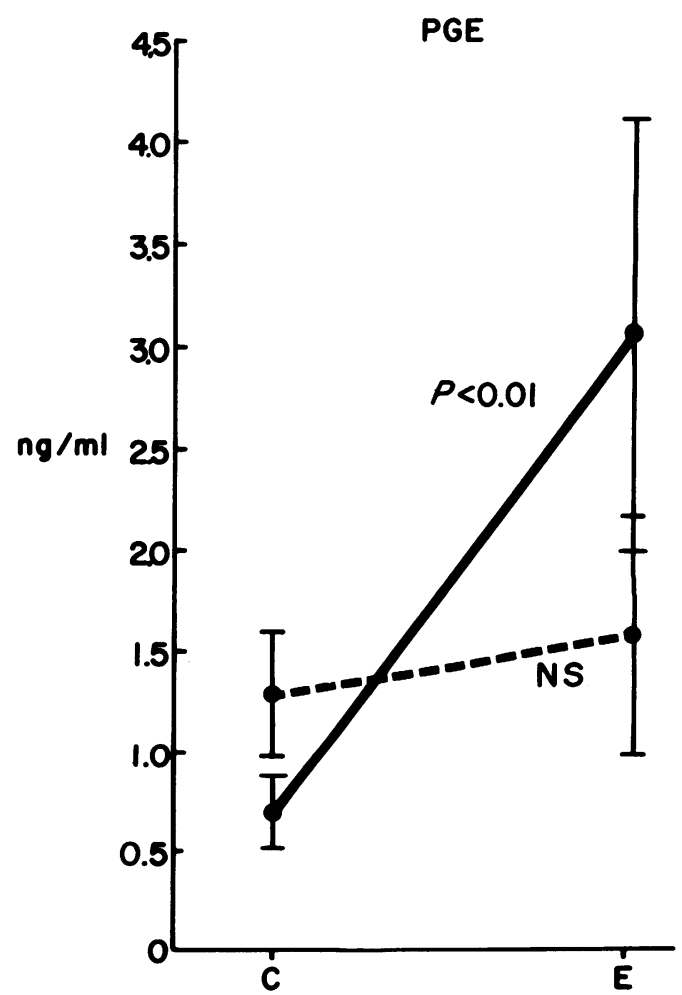

FIgure 4 Contralateral Renal vein PGE after renal artery stenosis. Renal vein PGE concentration in the contralateral kidney after renal artery stenosis in normal $(\longrightarrow)$ and indomethacin treated dogs $(---)$. 
before and $1.64 \pm 0.53$ (NS) after renal artery stenosis (Fig. 4).

\section{DISCUSSION}

An effect of the sympathetic nervous system on urinary dilution was shown in 1952 by Smythe et al. who demonstrated that epinephrine and norepinephrine increased free water clearance without change in renal hemodynamics or osmolar clearance (4). Similarly, in the experiments we report acute renal artery stenosis produced a decrease in Uosm and increased in free water clearance in the contralateral kidney with no change in GFR, renal blood flow, or osmolar clearance. Many studies have pointed to the role of baroreceptors altering $\mathrm{ADH}$ secretion during systemic hemodynamic changes. For instance, nonhypotensive hemorrhage blunts and distention of the left atrium increases a water diuresis independent of plasma osmolality (16) (3). However, in other animal and human experiments alterations in ADH secretion in response to baroreceptor stimulation is not a sufficient explanation for the changes which occur. In anesthetized and conscious dogs the water diuresis associated with left atrial distention is not abolished by physiological doses of vasopressin $(17,18)$ and norepinephrine increases free water clearance in water loaded subjects despite infusion of vasopressin (7). Similarly when the rise in MAP induced by acute renal artery stenosis was prevented by Arfonad in Group II, no change in baroreceptor tone should have occurred, but Uosm fell and free water clearance increased. In contrast, Saralasin, a specific angiotensin inhibitor, returned both MAP and free water clearance to control (Fig. 2). Although both Arfonad and Saralasin had a similar effect on MAP and presumably baroreceptor tone only Saralasin reversed the changes in urine volume and osmolality. This effect of Saralasin might have been due either to antagonism of an action of angiotensin inhibiting ADH secretion or to decreased collecting tubule sensitivity to ADH.

Some studies have suggested that angiotensin stimulates $\mathrm{ADH}$ secretion $(19,20)$. However, intracarotid angiotensin was found to have no effect on $\mathrm{ADH}$ secretion in dogs subjected to nonhypotensive hemorrhage (21) and Cadnapaphornchai et al. were unable to demonstrate that intracarotid infusion of angiotensin altered free water clearance during either hydropenia or water diuresis in anesthetized dogs (6). To eliminate angiotensin induced alterations in plasma ADH concentration Group IV dogs were hypophysectomized before clamping the renal artery. While the physiologic concentration of vasopressin in the dog is unknown, in man, Robertson et al., has suggested it may be as low as $2.8 \mathrm{pg} / \mathrm{ml}$ or approximately $1 \mu \mathrm{U} / \mathrm{ml}(22)$. In hypophysectomized dogs $10 \mu \mathrm{U} / \mathrm{kg}$ per min was infused which was suffi- cient to increase Uosm to approximately $700 \mathrm{mos} M / \mathrm{kg}$. Despite a continuous ADH infusion acute renal artery stenosis still produced a fall in Uosm and a rise in free water clearance. Such results cannot be explained by changes in circulating ADH concentration and antagonism to ADH must be occurring. This antagonism to ADH appears to be competitive since increasing the infusion of $\mathrm{ADH}$ to $80 \mu \mathrm{U} / \mathrm{kg}$ per min increased Uosm. Although hypotonic urine did not develop after renal artery stenosis in any of the six hypophysectomized dogs receiving $10 \mu \mathrm{U} / \mathrm{kg}$ per min of vasopressin it might have occurred if the dose of vasopressin had been reduced.

Hypertension is known to be associated with an exaggerated natriuresis during volume expansion (23, 24 ), and in rats with Goldblatt or spontaneous hypertension transit time, and fractional water absorption through the loop of Henle is decreased (24). With volume expansion hypertensive animals had a greater increase in urine volume, sodium excretion, osmolar clearance, and $\mathrm{Tc}_{\mathrm{H}_{2} \mathrm{O}}$ which was felt to be caused by increased pressure in the medullary circulation decreasing sodium reabsorption in the loop of Henle. Such an explanation would not explain our results for several reasons. First, the increase in $\mathrm{C}_{\mathrm{H}_{2} \mathrm{O}}$ occurred without a change in osmolar clearance and without a rise in blood pressure in Group II which received Arfonad. In addition, in Group III the increase in sodium excretion persisted during the infusion of Saralasin (Period III) despite reversal of the changes in $\mathrm{C}_{\mathrm{H}_{2} \mathrm{O}}$ and Uosm. Finally, the dose dependency of the antagonism also argues against the effect being due to increased medullary pressure.

McGiff et al. first reported an increase in contralateral renal vein PGE concentration after renal artery stenosis by using a bioassay for PGE (25). The rise we found in contralateral renal vein PGE after renal artery stenosis (Fig. 4) and the prevention of the diuresis with indomethacin makes increased PGE synthesis a possible cause of the ADH antagonism. The mechanism of angiotensin increasing PGE synthesis is not known but in cell cultures angiotensin stimulates acyl hydrolase which would increase the breakdown of arachidonic acid, the substrate for PGE synthesis, from medullary phospholipid (26). The fact that base-line renal vein PGE concentration was not lower in the Indocintreated animals (Fig. 4) reflects the variability in renal vein PGE concentration in different animals presumably because of differences in base-line renal blood flow, renin secretion, or sympathetic nervous activity. In a larger group of Indocintreated animals a difference in base-line PGE concentration might have been demonstrated.

A change in prostaglandin synthesis could effect response to $\mathrm{ADH}$ by causing redistribution of renal cortical blood flow. In the anesthetized dog indo- 
methacin decreases inner cortical and presumably medullary blood flow (27). A decrease in medullary blood flow could diminish solute washout increasing medullary tonicity and responsiveness to ADH. However, we found no change in either renal blood flow or cortical blood flow distribution after renal artery stenosis in the contralateral kidney (Fig. 1). The dose dependency of the ADH antagonism also makes an effect based upon change in renal hemodynamics unlikely since $80 \mu \mathrm{U} / \mathrm{kg}$ per min of Pitressin caused no hemodynamic change but increased Uosm (Group IV, Period III).

Since the hydro-osmotic effect of ADH depends upon activation of collecting tubule adenyl cyclase (28) PGE could alter sensitivity through change in concentration of cyclic AMP at the collecting tubule. In vitro beta adrenergic drugs increase and alpha adrenergic drugs decrease renal cyclic AMP generation but in the toad bladder an effect of catecholamines on water movement can only be demonstrated in the presence of vasopressin (29) (30). Similarly the effect of PGE in both toad bladder and collecting duct may be due to inhibition of $\mathrm{ADH}$ activation of adenyl cyclase since PGE causes no inhibition of water movement induced by cyclic AMP (31).

The failure to demonstrate a change in contralateral renal hemodynamics with an increase in plasma renin might also be due to increased PGE synthesis in the contralateral kidney. Angiotensin causes greater renal vasoconstriction in the prostaglandin-depleted animal (32) and there is evidence that tachyphylaxis to angiotensin is due to stimulation of PGE synthesis since it does not occur after prostaglandin inhibition (33). Since the nonosmotic stimuli which stimulate $\mathrm{ADH}$ release, i.e., diminished effective plasma volume, also increase renin secretion the teleologic significance of angiotensin increasing PGE synthesis with antagonism to ADH is unclear but PGE may be important in preventing the renal vasoconstrictive effect of angiotensin in high renin states.

This relationship between angiotensin, PGE, and ADH may have relevance to other studies of sympathetic function and free water clearance. In the dog, Schrier and colleagues (34), demonstrated an antidiuretic effect of isoproteronol only when the drug was given systemically and no effect in hypophysectomized dogs. They interpreted their results to indicate that the antidiuresis of beta adrenergic stimulation was mediated by increased ADH secretion in response to an alteration in systemic hemodynamics. Similarly, norepinephrine did not cause a diuresis in hypophysectomized dogs receiving $80 \mu \mathrm{U} / \mathrm{kg}$ per min of vasopressin which seemed to indicate that the effect of norepinephrine on free water clearance was mediated through altering ADH secretion (35). However, norepinephrine (36), angiotensin, and renal nerve stimulation (36) are all known to increase PGE synthesis and, as we have found, an infusion of 80 $\mu \mathrm{U} / \mathrm{kg}$ per min of vasopressin may block the demonstration of ADH antagonism. Similarly, an effect of angiotensin, norepinephrine, and renal nerve stimulation on collecting tubule sensitivity to ADH may not be detected if the renin-angiotensin and sympathetic nervous systems are stimulated during the control period. Several studies of the effect of angiotensin and norepinephrine on ADH sensitivity have been conducted during supra renal clamping of the aorta, which maintains consistency of renal perfusion pressure but raises control renal renin and PGE synthesis. Elevated controlled PGE synthesis might make a further increase during experimental maneuvers difficult to detect.

In contrast to the ADH antagonism which develops acutely with renal artery stenosis, in clinical states associated with hypertension and high plasma renin, i.e., malignant hypertension or renal artery stenosis, hyponatremia is frequently present (37). This would imply greater sensitivity or increased secretion of ADH in those conditions. Decreased medullary PGE synthesis has been reported in rats after chronic unilateral renal artery stenosis $(38,39)$ and conceivably the increase in renal PGE synthesis with acute renal artery stenosis is not sustained with chronic stimulation. If PGE medullary depletion occurs during renal hypertension increased sensitivity to ADH might occur with resultant hyponatremia. The effect of chronic or acute hypertension in man on renal medullary PGE synthesis is unknown. Studies utilizing urinary PGE determinations in various clinical settings might help elucidate these questions.

\section{ACKNOWLEDGMENTS}

The authors acknowledge the expert technical assistance of Ms. Linda Howe, Elena Popescu, Rosemary Reed, and Gail Johannes in the performance of these studies.

This study was supported by research grants HL 13653, HL 5957, from the National Institutes of Health, and grants from the Central Ohio Heart Chapter of the American Heart Association.

\section{REFERENCES}

1. Schrier, R. W., and T. Berl. 1975. Nonosmolar factors affecting renal water excretion. N. Engl. J. Med. 292: 81-88, 141-145.

2. Share, L., and M. N. Levy. 1962. Cardiovascular receptors and blood titer of antidiuretic hormone. Am.J. Physiol. 203: 425-428.

3. Henry, J. P., O. H. Gauer, and J. L. Reeves. 1956. Evidence of the atrial location of receptors influencing urine flow. Circ. Res. 4: 85-90.

4. Smythe, C. M., J. F. Nickel, and S. E. Bradley. 1952. The effect of epinephrine (USP), 1-epinephrine, and 1-norepinephrine on glomerular filtration rate, renal plasma flow, and the urinary excretion of sodium, potassium, and water in normal man. J. Clin. Invest. 31: 499-506.

5. Baldwin, D. S., E. A. Gombos, and H. Chasis. 1963. 
Changes in sodium and water excretion induced by epinephrine and 1-norepinephrine in normotensive hypertensive subjects. J. Lab. Clin. Med. 61: 832-857.

6. Cadnapaphornchai, P., J. Boykin, J. A. Harbottle, K. M. McDonald, and R. W. Schrier. 1975. Evaluation of effect of angiotensin II on renal water excretion. Am. J. Physiol. 228: 155-159.

7. Fisher, D. A. 1968. Norepinephrine inhibition of vasopressin antidiuresis. J. Clin. Invest. 47: 540-547.

8. Grantham, J. J., and J. Orloff. 1968. Effect of prostaglandin $E_{1}$ on the permeability response of the isolated collecting tubule to vasopressin, adenosine $3^{\prime}, 5^{\prime}$-monophosphate, and theophylline. J. Clin. Invest. 47: 1154-1161.

9. Änggård, E., S. O. Bohman, C. Larsson, J. E. Griffin, III, and A. B. Maunsback. 1972. Subcellular localization of the prostaglandin system in the rabbit renal papilla. Acta Physiol. Scand. 84: 231-246.

10. Janszen, F. H., and D. H. Nugteren. 1971. Histochemical localisation of prostaglandin synthetase. Histochemie. 27: 159-164.

11. Vane, J. R., and J. C. McGiff. 1975. Possible contributions of endogenous prostaglandins to the control of blood pressure. Circ. Res. Suppl. 1: 68-75.

12. Domensch, R. J., J. I. E. Hoffman, M. I. M. Noble, K. B. Saunders, H. R. Henson, and S. Subijanto. 1969. Total and regional coronary blood flow measured by radioactive microspheres in conscious and anesthetized dogs. Circ. Res. 25: 581-596.

13. Rector, J. B., J. H. Stein, W. H. Bay, R. W. Osgood, and T. F. Ferris. 1972. Effect of hemorrhage and vasopressor agents on distribution of renal blood flow. Am. J. Physiol. 222: 1125-1131.

14. Haber, E., T. Koem, L. B. Page, B. Kliman, and A. Purnode. 1969. Application of a radioimmunoassay for angiotensin I to the physiologic measurements of plasma renin activity in normal human subjects. $J$. Clin. Endocrinol. Metab. 29: 1349-1355.

15. Venuto, R. C., T. O’Dorisio, J. H. Stein, and T. F. Ferris. 1975. Uterine prostaglandin $E$ secretion and uterine blood flow in the pregnant rabbit. J. Clin. Invest. 55: 193-197.

16. Amdt, J. O. 1965. Diuresis induced by water infusion into the carotid loop and its inhibition by small hemorrhage. The competition of volume and osmocontrol. Pfluegers Arch. Eur. J. Physiol. 282: 313-322.

17. Ledsome, J. R., R. J. Linden, and W. J. O'Connor. 1961. The mechanisms by which distention of the left atrium produces diuresis in anesthetized dogs. $J$. Physiol. (Lond.). 159: 87-100.

18. Lydtin, H., and W. F. Hamilton. 1964. Effect of acute changes in left arterial pressure on urine flow in unanesthetized dogs. Am. J. Physiol. 207: 530-536.

19. Mouw, D., J. P. Bonjour, R. L. Malvin, and A. Vander. 1971. Central action of angiotensin in stimulating ADH release. Am. J. Physiol. 220: 239-242.

20. Selkurt, E. E. 1951. Effect of pulse pressure and mean arterial pressure modification on renal hemodynamics and electrolyte and water excretion. Circulation. 4: 541-551.

21. Claybaugh, J. R., L. Share, and K. Shimizu. 1972. The inability of infusions of angiotensin to elevate the plasma vasopressin in the anesthetized dog. Endocrinology. 90: 1647-1652.

22. Robertson, G. L., E. A. Mahr, S. Athar, and T. Sinha. 1973. Development and clinical application of a new method for the radioimmunoassay of arginine vasopressin in human plasma. J. Clin. Invest. 52: 23402352 .
23. Papper, S., J. L. Belsky, and K. H. Bliefer. 1960. The response to the administration of an isotonic sodium chloride-lactate solution in patients with essential hypertension. J. Clin. Invest. 39: 876-884.

24. Stumpe, K. O., H. D. Lowitz, and B. Ochwadt. 1970. Fluid reabsorption in Henle's loop and urinary excretion of sodium and water in normal rats and rats with chronic hypertension. J. Clin. Invest. 49: 1200-1212.

25. McGiff, J. C., K. Crowshaw, N. A. Terragno, and A. J. Lonigro. 1970. Release of a prostaglandin-like substance into renal venous blood in response to angiotensin II. Circ. Res. 26, 27 (Suppl I): 121-130.

26. Gimbrone, M. A., Jr., and R. W. Alexander. 1975. Angiotensin II stimulation of prostaglandin production in cultured human vascular endothelium. Science (Wash. D. C.). 189: 219-220.

27. Kirschenbaum, M. A., N. White, J. H. Stein, and T. F. Ferris. 1974. Redistribution of renal cortical blood flow during inhibition of prostaglandin synthesis. Am. J. Physiol. 227: 801-805.

28. Orloff, J., and J. Handler. 1967. The role of adenosine $3^{\prime}, 5^{\prime}$-phosphate in the action of antidiuretic hormone. Am. J. Med. 42: 757-768.

29. Beck, N. P., S. W. Reed, H. V. Murdaugh, and B. B. Davis. 1972. Effects of catecholamines and their interaction with other hormones on cyclic $3^{\prime}, 5^{\prime}$-adenosine monophosphate of the kidney. J. Clin. Invest. 51: 939944.

30. Handler, J. S., R. Bensigner, and J. Orloff. 1968. Effect of adrenergic agents on toad bladder response to $\mathrm{ADH}$, 3',5'-AMP and theophylline. Am. J. Physiol. 215: 10241031 .

31. Orloff, J., J. S. Handler, and S. Bergstrom. 1965. Effect of prostaglandin $\left(\mathrm{PGE}_{1}\right)$ on the permeability response of toad bladder to vasopressin, theophylline and adenosine 3',5'-monophosphate. Nature (Lond.). 205: 397-398.

32. Aiken, J. W., and J. R. Vane. 1973. Intrarenal prostaglandin release attenuates the renal vasoconstrictor activity of angiotensin. J. Pharmacol. Exp. Ther. 184: 678-687.

33. Aiken, J. W. 1974. Effects of prostaglandin synthesis inhibitors on angiotensin tachyphylaxis in the isolated coeliac and mesenteric arteries of the rabbit. Pol. J. Pharmacol. Pharm. 26: 217-227.

34. Schrier, R. W., R. Lieberman, and R. C. Ufferman. 1972. Mechanism of antidiuretic effect of beta adrenergic stimulation. J. Clin. Invest. 51: 97-111.

35. Schrier, R. W., and T. Berl. 1973. Mechanism of the effect of alpha adrenergic stimulation with norepinephrine on renal water excretion. J. Clin. Invest. 52: 502511.

36. McGiff, J. C., K. Crowshaw, N. A. Terragno, K. U. Malik, and A. J. Lonigro. 1972. Differential effect of noradrenaline and renal nerve stimulation on vascular resistance in the dog kidney and the release of a prostaglandin E-like substance. Clin. Sci. (Oxf.). 42: 223233.

37. Brown, J. J., D. L. Davies, A. F. Lever, and J. I. S. Robertson. 1965. Plasma renin concentration in human hypertension. Relationship between renin, sodium, and potassium. Br. Med.J. 2: 144-148.

38. Ishii, M., and L. Tobian. 1969. Interstitial cell granules in renal papilla and the solute composition of renal tissue in rats with Goldblatt hypertension. J. Lab. Clin. Med. 74: 47-52.

39. Pugsley, D. J., L. J. Beilin, and R. Peto. 1975. Renal prostaglandin synthesis in the Goldblatt hypertensive rat. Cir. Res. 1 (Suppl.): 81-88. 